\title{
Enhancing Students' Speaking Ability by Using Story Telling Technique (STT)
}

\author{
Andrian $^{1}$, Faudi $^{2}$ \\ ${ }^{1}$ STKIP An-Nur Nanggroe Aceh Darussalam, Indonesia \\ ${ }^{2}$ Universitas Serambi Mekkah, Indonesia \\ andrian_bna@yahoo.com
}

\begin{abstract}
Enhancing Students' Speaking By Using Story Telling Technique (STT) (An Experimental Research at MTsN 2 Aceh Besar). This research aimed to find out the students' speaking ability by using story telling technique, the focus is on fluency and vocabulary in speaking. The instruments of the researcher is test and questionnaires. The main subjects of this researcher are 32 students of VIII-I at MTsN 2 Aceh Besar. The data quantitative and qualitative. The quantitative data is gained from test and the qualitative data is gained from questionnaires. After analyzing data, the score of pre-test the lowest score is 20 and the higher score is 50. After applying the technique she give the students posttest score could be seen in the table 4.1.6 (60 and 85). While the lowest value of questionnaires is $0 \%$ and the highest value is $68.75 \%$. Based on the score, it is suggested that the teacher should help and understand their students before teaching them. This can be done by giving the students' chose to ask questions, involve in discussing, express their ability in English, and try to help the students to investigate and solve their problems in learning English. Moreover, the students should increase their ability in English by trying to enrich their knowledge and reading related books.
\end{abstract}

Keywords

speaking ability, student; story telling technique

\section{Introduction}

Speaking is the productive skill ability that could be not separated from someone. Speaking is part of the language ability which is important for language learners to be developed. As social human, people always interact and communicate one another. The first way to do the interaction and communication is by speaking. In this case, the people express their ideas and communicate what they want orally. That is why speaking is very essential, moreover speaking English. Aye and Phyu (2015: 1) state that we need an effective English speaking skill in the whole life aspects in this globalization era.

English has become an International language of communication. English language learners are required not only to understand and deliver message in a written form, but also to understand messages presented orally, such as understanding the content of speech and to deliver their thoughts, feeling and experiences for communicative purposes and students are demanded to be able to face global competition. This condition encourages the research to help students to be better prepared.Then, Sepahvand (2014: 47) argues that there are some reasons to put speaking as the first aim of study such as personal satisfaction from being able to speak and reach other interests or career goals. 
In the Content standard, the main purpose of learning is based on the achievement of its competency. All activities carried out in class focused on one goal that is to gain the competency in using language for communication.In other words, it is planned to force the students to master how to use language in different situations for different communicative purposes.Additionally, Tahir (2015: 174) says that somebody is considered successful in learning a foreign language when he or she has the ability to speak it andstudents learn to communicate by practicing communication. This is the main principle of developing students' competencies using dialogues, fluency implementation of each teaching learning process in communicative context and also present functions and conversational expressions. Tarigan (2015:3-4) defines that speaking is a language ability that is developed in child life, which is produced by listening skill, and at that period speaking ability more impact on student growth. Speaking ability is not only improving in pronunciation but also engaging in vocabulary and fluency.

\section{Review of Literature}

\subsection{The Concept of Speaking Skill}

Speaking is the important tools in human daily life, how the people interaction to each other. According to Hornby (1995:826) speaking is making use of words in an ordinary voice, offering, words, knowing and being able to use a language expressing one-self in word, and making speech. Therefore the researcher infers that speaking uses the word and produces the sound to express ourselves either ideas, feeling, thought and needs orally in an ordinary voice and the success in communication often depends on speaking skill. Hasibuan et al (2019) stated that Speaking is the ability will not develop if not trained continuously. Therefore, the speaking ability of children will not be mastered properly without being trained routinely. If it is always trained, the ability to speak will certainly be better. Meanwhile Sari and Sembiring (2019) argued that Speaking is a language skill that has to be mastered by students in learning a language because the objective of learning a language is communication.

In addition, speaking is a spoken productive language skill. It is about how the students produce the language orally. Furthermore, according to Harmer, Speaking refers to the students produce pieces of language and sees how its turns out that information are feedback into the acquisition process. Therefore, speaking focused on output where the learner's attention is on conveying ideas and messaging to another person. As Jones comments that in speaking and listening we tend to be getting something done, exploring ideas, working out some aspect of the world, or simply being together. In writing, we may be creating a record, committing events or moments to paper.

\subsection{The Elements of Speaking}

The basic assumption in any oral interaction is that the speaker wants to communicate ideas, feelings, attitudes and information to the hearer or wants to employ speech that relates to the situation. Therefore, the ability to speak fluently presupposes not only knowledge the language features, but also the ability to process the information and language 'on the spot'.

The delivery of your speech in public relies on various elements from overcoming a fear of crowds to your knowledge on a topic. Whether you've delivered speeches before, or it's your first time, it is important that you say it effectively in order to maximize the impact on your audience. The following are elements you should have to ensure your speech is not just well done, but manages to get its message across expertly. 


\subsection{Teaching of Speaking Skill}

Teaching speaking is really different, unlike teaching listening, writing, and reading. Speaking needs a habit formation because it is a real communication. Speaking only need practice more over. So the researcher believes that if the student always practice the English language, they should be mastery English language by easily. According to Hornby (1995:37) teaching means giving the instruction to (a person): give a person (knowledge skill). While speaking means to make use of words in an ordinary voice. So, teaching speaking is giving instruction to a person in order to communicate. And in another source Speaking is "the process of building and sharing meaning through the use of verbal and non-verbal symbols, in a variety of contexts".

Speaking is a crucial part of second language learning and teaching. However, the goal of second of teaching speaking should improve the students' communicative skills because, students can express themselves and learn how to use a language. Nowadays, many teachers agree that students should learn to speak the foreign language by interacting to each other. In this case, students should master several speaking components', such as vocabulary and fluency. In brief, English teachers should be creative in developing their teaching process to create good atmosphere, improve the students speaking skill, give attention to the speaking components and make the English lesson more exciting.

In this research, the researcher applied the student talk activities on herteaching speaking in class ability by using story telling technique. STT is the learning model that applied research she as a teacher taught students on applying STT. The teacher measured the students speaking skill by giving a test. Oller (1979: 1) argued "language test as a device that tries to assess how many students have learned a foreign language course or some parts of course". In this definition, Oller refers to the measurement of how far students master the learning materials and reach the objective of language course. In this research, the teacher conducted the test to measure the speaking ability of the students. In other words, the teacher measured the students speaking skill from three elements of speaking skill. Hence, there are three important things that should be explained. Such things include the accuracy of vocabulary and fluency.

\subsection{Story Telling Technique}

Story telling technique is an oral activity to grab audience attention by using multiply sensory stirring emotion of an event in a story, it involves improvisation in telling story, facial gestures, and body movement Stanley and Dillingham, (2009: 4). As a part of speaking activities in the class, storytelling also an effective teaching tool that enables students to focus on story structure. Story telling is a procedure that enables a child to play a large role in reconstructing stories. It underlines both social and academic development. When they tell a story, they use language for an extended period of time.

They construct the story this activity increases their language development. When narrating stories, the speaker uses the language for an extended period of time. This active participation with stories results in increased language development, comprehension and an interest in books and in learning to read. Telling after reading provides another opportunity for the reader to reconstruct the text. Telling story is an active process that encourages children to reconstruct the text, it also allows for interaction between tutor and child. When necessary, teacher can help the child reconstruct the meaning of the text by using open-ended questions and lead-in to facilitate. For example, if a child pauses and seems confused, ask, what happened next? If a child needs help detailing a main character, say, Tell me more about this character (Gibson, 2003:1). 


\subsection{Teaching Speaking Ability by Using Story Telling Technique}

Storytelling technique is the original form of teaching. There are still societies inwhich it is the only form of teaching. Though attempts have been made to imitate orupdate it, like the electronic storytelling technique of television, liveoral

storytelling technique will never go out of fashion. A simple narrative will always be the cornerstone of the art of teaching. Colloquial or literary, unaffected or flowery the full range of language is present in stories develop in a unique way. The listeners benefit from observing non polished speech created on the spot. While listening to stories, children develop a sense of structure that will later help them to understand the more complex stories of literature. In fact, stories are the oldest form of literature.

The use of literature in foreign language teaching has greatly increased over the past few years. The materials and activities that derive from literacy texts are a great aid tolearning in that they appeal to the learners' imagination, increase motivation and, above all, create a rich and meaningful context. Among the techniques available to the teacher, storytelling technique is one of the most frequently used, especially with beginners. And false beginners. Zaro and Salaberry,(1995:2), storytelling is an established part of the curriculum inboth English-speaking countries and many others, and stories are seen as a first-rate resource in the teaching of the child's own language.

\section{Research Methods}

This chapter focuses on the research method employed in the present research. In general, the discussion includes eight headings, they are: The Research Design, Location and Time of Research, The Students, The Teacher, Population and Sample, Instruments and Technique of Data Analysis.

The design used in this research is a quantitative and qualitative design. This type of research in this students is an experimental research design with one group pre-test and posttest design described as follows: Ary, Jocobs dan Serensen (2010: 123).

Table 1. Group Pre-test and Post-test Design

\begin{tabular}{|c|c|c|}
\hline Pre-test & Variable Independent & Post-test \\
\hline $\mathrm{Y} 1$ & $\mathrm{X}$ & $\mathrm{Y} 2$ \\
\hline
\end{tabular}

In which;

$$
\begin{aligned}
& X: \text { STT } \\
& Y_{1} \text { : Data Pre-test } \\
& Y_{2}: \text { Data Post-test }
\end{aligned}
$$

The population of this research is the firstyear students at MTsN 2 Aceh Besar. The number of Population is 150 Students and it is divided into seven classes. Talking about the sample, Sutrisno (1965:54), says that sample is a part of the whole object/individual which be researched, which able to represent the population.

In this case, the researcher took one class as the sample of the research. So, the number of sample is about 32 students. This number is representative based on the theory state that the sample may not less $10 \%$ of the Population.

In analyzing the questionnaires, the researcher used the percentage system, and the formula as sussgested by Sudjana (2005:67) 


$$
P=\frac{f}{n} x 100 \%
$$

In which:

$$
\begin{aligned}
& \mathrm{p}=\text { Percentage } \\
& \mathrm{f}=\text { Frequncy of respondents } \\
& \mathrm{n}=\text { Number of respondents } \\
& 100 \%=\text { Constant value }
\end{aligned}
$$

Pre-test and post-test data of students' speaking abilities were analyzed by using the right-hand independent $t$ test. This was done to find out the students' speaking ability after using STT at MTsN 2 Aceh Besar. Before testing the dependent $t$ test, normality and homogeneity tests are first performed. If the pre-test or post-test data concludes that the data does not originate from the normal distribution population and do not have the same variance, the test is performed using the $\mathrm{t}$ test.

\section{Normality Test}

Normality test is used to know whether data comes from a normal distribution population or not. The hypothesis formulated is as follows.

$\mathrm{H}_{0}$ : Data comes from a normal distribution population

$\mathrm{H}_{\mathrm{a}}$ : Data comes from a not normal distribution population

The formula $X^{2}$ is as follow: Subana, Rahadi dan Sudraja (2000: 125)

$$
X^{2}=\sum_{i=1}^{k} \frac{\left(0_{i-} E_{i}\right)^{2}}{E_{i}}
$$

In Which:

$\mathrm{X}^{2}$ : value chi square

$\mathrm{E}_{\mathrm{i}}$ : frequency expectations

$0_{\mathrm{i}}$ : frequency observation

The conclusion obtained with the criteria: "Total $\mathrm{H}_{0}$ if $X^{2}$ count $\geq X^{2}$ table and for other values $\mathrm{H}_{0}$ is accepted".

Mann-Whitney Testing using the Z Test Approach

As cited in Hendrik (2011: 110) Triola states that for the steps in carrying out the Mann-Whitney test using the $\mathrm{z}$ test approach are as follows:

1. Formulate the null hypothesis and alternative hypotheses

Determine the lever of significance ( $\alpha$ ). example $\alpha=0,05$ or $\alpha=0,01$

2. Merge data from both groups and sort the data from the lowest to the highest in a group cell

3. Rank each data in the group cell. Ranking 1 is given to the lowest data. If there are no data together then the order is the same as ranking. However, if there is the same data then the (R) rank is calculated by the following formula:

$$
\mathrm{R}=\frac{\text { the number of sequences of data that have the same value }}{\text { lost of data with the same value }}
$$

4. Regroup the data that has been ranked into the initial group of observations

5. Determine R1 and R2 ie: 
- $\mathrm{R}_{1}$ is the number of ranks in the group 1

- $\mathrm{R}_{2}$ is the number of ranks in the group 2

6. Determine $\mathrm{R}_{1}$ average, $\mathrm{R}_{2}$ average, standard error ranking, and $\mathrm{Z}_{\text {calculate }} \mathrm{using}$ the following formula:

$$
\begin{aligned}
& \tilde{\mu}_{1}=\frac{n 1(n 1+n 2+1)}{2} \quad \mu \mathrm{R}_{2}=\frac{n 2(n 1+n 2+1)}{2} \\
& \check{\sigma}_{\mathrm{R}}=\sqrt{\frac{n 1 x n 2 x(n 1+n 2+1)}{12}} \\
& \mathrm{Z}_{\text {calculate }}=\frac{R 1-\widetilde{\mu} \mathrm{R} 1}{\delta R}
\end{aligned}
$$

Where;

$\begin{array}{ll}\mathrm{n}_{1} & : \text { many of data group } 1 \\ \mathrm{n}_{2} & : \text { many of data group } 2 \\ \mathrm{R}_{1} & : \text { The number of ranks in group 1 } \\ \mathrm{R}_{2} & : \text { The number of ranks in group } 2 \\ \tilde{\mu} \mathrm{R}_{1} & : \text { Average group ranking } 1\end{array}$

\section{Discussion}

Teaching speaking is really different, unlike teaching listening, writing, and reading. Speaking needs a habit formation because it is a real communication. Speaking only needs practice more over and over. So the researcher believes that if the students always practice the English language, they should be mastery English language easily. According to Hornby (1995: 37) teaching means giving the instruction to (a person): give a person (knowledge skill). While speaking means to make use of words in an ordinary voice. So, teaching speaking is giving instruction to a person in order to communicate. The process of building and sharing meaning through the use of verbal and non-verbal symbols, in a variety of contexts. Speaking is a crucial part of second language learning and teaching. However, the goal of second of teaching speaking should improve the students' communicative skills because, students can express themselves and learn how to use a language. Nowadays, many teachers agree that students should learn to speak the foreign language by interacting to each other. In this case, students should master several speaking components', such as vocabulary and fluency. Briefly, English teachers should be creative in developing their teaching process to create good atmosphere, improve the students interest in speaking skill, give their attention to the speaking components and make the English lesson more exciting.

In this research, the researcher applied the story telling technique in her teaching. STT is one of learning technique that applied by the researcher in conducing her research. The researcher measured the students speaking skill by giving a test. Oller (1979: 1) argued "language test as a device that tries to assess how many students have learned a foreign language courses or some parts of courses". In this definition, Oller refers to the measurement of how far students master the learning materials and reach the objective of language courses. In this research, the researcher conducted the test to measure the students' speaking ability. In other words, the researcher measured the students speaking skill from two elements of speaking skill; Hence, there are two important things that should be mastered such as vocabulary and fluency. 
To be clearer, it is better to see the data collected (students' scores) in the following tables:

Table 2. Result of Pre-Test and Post-Test

\begin{tabular}{|c|c|c|c|}
\hline No & Number of Students & Pre-Test & Post-Test \\
\hline 1 & 1 & 50 & 75 \\
\hline 2 & 2 & 20 & 60 \\
\hline 3 & 3 & 50 & 85 \\
\hline 4 & 4 & 20 & 60 \\
\hline 5 & 5 & 40 & 70 \\
\hline 6 & 6 & 30 & 70 \\
\hline 7 & 7 & 40 & 70 \\
\hline 8 & 8 & 40 & 60 \\
\hline 9 & 9 & 40 & 70 \\
\hline 10 & 10 & 35 & 70 \\
\hline 11 & 11 & 50 & 80 \\
\hline 12 & 12 & 50 & 80 \\
\hline 13 & 13 & 40 & 75 \\
\hline 14 & 14 & 30 & 75 \\
\hline 15 & 15 & 20 & 60 \\
\hline 16 & 16 & 20 & 60 \\
\hline 17 & 17 & 30 & 60 \\
\hline 18 & 18 & 30 & 70 \\
\hline 19 & 19 & 40 & 60 \\
\hline 20 & 20 & 40 & 70 \\
\hline 21 & 21 & 20 & 70 \\
\hline 22 & 22 & 30 & 70 \\
\hline 23 & 23 & 30 & 70 \\
\hline 24 & 24 & 35 & 75 \\
\hline 25 & 25 & 35 & 75 \\
\hline 26 & 26 & 20 & 60 \\
\hline 27 & 27 & 20 & 60 \\
\hline 28 & 28 & 40 & 80 \\
\hline 29 & 29 & 40 & 80 \\
\hline 30 & 30 & 35 & 60 \\
\hline 31 & 31 & 35 & 60 \\
\hline 32 & 32 & 50 & 80 \\
\hline Total & & 1.105 & 2.065 \\
\hline
\end{tabular}

$$
X^{2}=\sum_{i=1}^{k} \frac{\left(0_{i-1} E_{i}\right)^{2}}{E_{i}}
$$

It is known that the numeracy skills obtained in the research can be presented in the following table: 
Table 3. Result of Pre-Test

\begin{tabular}{|c|c|}
\hline Test Scores & Frequency (f) \\
\hline $20-25$ & 8 \\
\hline $26-31$ & 6 \\
\hline $32-37$ & 5 \\
\hline $38-43$ & 9 \\
\hline $44-49$ & 0 \\
\hline $50-55$ & 4 \\
\hline
\end{tabular}

Determine whether the data is normally distributed!

Where;

The hypotheses formulated are as follows:

$\mathrm{H}_{0}$ : The data comes from normally distributed populations

$\mathrm{Ha}$ : Data comes from populations that are not normally distributed

Table 4. Result of Pre-Test

\begin{tabular}{|c|c|c|c|c|c|c|}
\hline No & Test Scores & $\mathbf{F}$ & $\mathbf{x}_{\mathbf{i}}$ & $\mathbf{x}_{\mathbf{i}}^{\wedge} \mathbf{2}$ & $\mathbf{f x}_{\mathbf{i}}$ & $\mathbf{f x}_{\mathbf{i}} \mathbf{\wedge}^{\mathbf{2}}$ \\
\hline 1 & $20-25$ & 8 & 23 & 506.25 & 180 & 4050 \\
\hline 2 & $26-31$ & 6 & 29 & 812.25 & 171 & 4873.5 \\
\hline 3 & $32-37$ & 5 & 35 & 1190.25 & 172,5 & 5951.25 \\
\hline 4 & $38-43$ & 9 & 41 & 1640.25 & 364.5 & 14762.25 \\
\hline 5 & $44-49$ & 0 & 47 & 2162.25 & 0 & 0 \\
\hline 6 & $50-55$ & 4 & 53 & 2756.25 & 210 & 11025 \\
\hline & Total & 32 & 225 & 9067.5 & 1098 & 40664 \\
\hline
\end{tabular}

Based on the above table, the average scores and standard deviations are as follows:

$\overline{\boldsymbol{x}}=\frac{\Sigma f i x i}{\Sigma f i}=\frac{1098}{32}=34.3125$

$\mathrm{S}=\frac{\sqrt{n \Sigma f i x 2 i-(\Sigma f i x i)^{2}}}{\mathrm{n}(\mathrm{n}-1)}=\frac{\sqrt{(32)(40662)-(1098)^{2}}}{32(32-1)}$

$S=\frac{\sqrt{1.301-1.206}}{32(31)}=\sqrt{0.096=0.3010}$

Table 5. Result of Pre-Test

\begin{tabular}{|c|c|c|c|c|c|c|}
\hline $\begin{array}{c}\text { Test } \\
\text { Second }\end{array}$ & $\begin{array}{c}\text { Class } \\
\text { Limit (x) }\end{array}$ & Z-score & BLDBKN & $\begin{array}{c}\text { Total } \\
\text { Area }\end{array}$ & $\begin{array}{c}\text { Expected } \\
\text { Frequency(Ei) }\end{array}$ & $\begin{array}{c}\text { Expected } \\
\text { frequency (Oi) }\end{array}$ \\
\hline & 19.5 & -1.5090398 & 0.4332 & & & \\
\hline $20-25$ & & & & 0.1199 & 3.8368 & 8 \\
\hline & 25.5 & -0.8977832 & 0.3133 & & & 6 \\
\hline $26-31$ & & & & 0.203 & 6.496 & \\
\hline & 31.5 & -0.2865265 & 0.1103 & & & 5 \\
\hline $32-37$ & & & & 0.2358 & 7.5456 & \\
\hline & 37.5 & 0.3243008 & 0.1255 & & & \\
\hline
\end{tabular}




\begin{tabular}{|c|c|c|c|c|c|c|}
\hline $38-43$ & & & & 0.1983 & 6.3456 & 9 \\
\hline & 43.5 & 0.93598669 & 0.3238 & & & \\
\hline $44-49$ & & & & 0.1144 & 3.6608 & 0 \\
\hline & 49.5 & 1.54724331 & 0.4382 & & & 4 \\
\hline $50-55$ & & & & 0.046 & 1.472 & \\
\hline & 55.5 & 2.15849993 & 0.4842 & & & 32 \\
\hline Total & 262.5 & 2.27311054 & 2.2285 & 0.9174 & 29.3568 & \\
\hline
\end{tabular}

In which:

1. Class limit $(\mathrm{x})=$ Lower limit -0.5

$$
\begin{aligned}
& =20-0,5 \\
& =19.5
\end{aligned}
$$

2. $\mathrm{z}$ for class limits

$$
\begin{gathered}
\mathrm{z}=\frac{x-\bar{x}}{s}, \text { with } \bar{x}=34.3125 \text { and } \mathrm{s}=0.3010 \\
\mathrm{Z}=\frac{19.5-34.3125}{0.3010} \\
\mathrm{Z}=-49.2116
\end{gathered}
$$

3. The area of the curve in each class is the same as the difference between

4. $\mathrm{Z}_{\mathrm{i}}$ with value $\mathrm{Z}_{(\mathrm{i}-1)}$.

$$
\begin{aligned}
& \text { Total area }=\left(-\mathrm{z}_{1}-\left(-\mathrm{z}_{2}\right)\right) \\
& =(0.4332-0.3133) \\
& =0.1199
\end{aligned}
$$

5. $=$ The area of each interval class $\mathrm{x}$ many classes

$=0.1199 \times 32$

$=3.8368$

Then the value of chi-squares count is as follows:

$$
\begin{aligned}
& X^{2}=\sum_{i=1}^{k} \frac{\left(0_{i-1} E_{i}\right)^{2}}{E_{i}} \\
& =\frac{(8-3.8368)^{2}}{3.8368}+\frac{(6-6.496)^{2}}{6.496}+\frac{(5-7.5456)^{2}}{7.5456}+\frac{(9-6.3456)^{2}}{6.3456}+\frac{(0-3.6608)^{2}}{3.6608} \\
& \qquad+\frac{(4-1,474)^{2}}{1.474} \\
& =4.52+0.04+0.86+1.11+3.66+4.33 \\
& =14.55
\end{aligned}
$$

With a significant level $a=0.05$ and many interval classes $k=6$ then the degree of freedom $(\mathrm{dk})$ for the chi square distribution the magnitude is

$\mathrm{dk}=\mathrm{k}-8=6-8=-2$ then $X_{\text {table }}^{2}=(1-\mathrm{a})(\mathrm{k}-8)=X^{2}(0-0.05)(6-8)=X^{2}(0.95)$ (8) from the list $\mathrm{H}$ obtained values $X^{2}$ table $=7.81$. therefore $X_{\text {count }}^{2}>X_{\text {table }}^{2}$ that is $14.55>7.81$ so $\mathrm{H}_{0}$ is not accepted and it can be concluded that the data come from populations the are not normally distributed. 


$$
X^{2}=\sum_{i=1}^{k} \frac{\left(0_{i-1} E_{i}\right)^{2}}{E_{i}}
$$

It is known that the numeracy skills obtained in the research can be presented in the following table:

Table 6. Result Post-Test

\begin{tabular}{|c|c|}
\hline Test Scores & Frequency (f) \\
\hline $60-64$ & 11 \\
\hline $65-69$ & 0 \\
\hline $70-74$ & 10 \\
\hline $75-79$ & 5 \\
\hline $80-84$ & 5 \\
\hline $85-89$ & 1 \\
\hline
\end{tabular}

Determine whether the data is normally distributed!

Where;

The hypotheses formulated are as follows:

$\mathrm{H}_{0}$ : The data comes from normally distributed populations

Ha : Data comes from populations that are not normally distributed

Table 7. Result of Post-Test

\begin{tabular}{|c|c|c|c|c|c|c|}
\hline No & Test Scores & $\mathbf{F}$ & $\mathbf{x}_{\mathbf{i}}$ & $\mathbf{x}_{\mathbf{i}}^{\wedge} \mathbf{2}$ & $\mathbf{f} \mathbf{x}_{\mathbf{i}}$ & $\mathbf{f x}_{\mathbf{i}} \mathbf{i}^{\mathbf{2}}$ \\
\hline 1 & $60-64$ & 11 & 62 & 3844 & 682 & 42284 \\
\hline 2 & $65-69$ & 0 & 67 & 4489 & 0 & 0 \\
\hline 3 & $70-74$ & 10 & 72 & 5184 & 720 & 51840 \\
\hline 4 & $75-79$ & 5 & 77 & 5929 & 385 & 26645 \\
\hline 5 & $80-84$ & 5 & 82 & 6724 & 410 & 33630 \\
\hline 6 & $89-89$ & 1 & 87 & 7569 & 87 & 7569 \\
\hline & Total & 32 & 447 & 33739 & 2284 & 164958 \\
\hline
\end{tabular}

Based on the table above, the average scores and standard deviations are as follows;

$$
\begin{aligned}
& \overline{\boldsymbol{x}}=\frac{\Sigma f i x i}{\Sigma f i}=\frac{2284}{32}=71.375 \\
& \mathrm{~S}=\frac{\sqrt{n \Sigma f i x 2 i-(\Sigma f i x i)^{2}}}{\mathrm{n}(\mathrm{n}-1)}=\frac{\sqrt{(32)(164958)-(2284)^{2}}}{32(32-1)} \\
& \mathrm{S}=\frac{\sqrt{5.276-5.216}}{32(31)}=\sqrt{0.06}=0.245
\end{aligned}
$$


Table 8. Result of Post-Test

\begin{tabular}{|c|c|c|c|c|c|c|}
\hline $\begin{array}{c}\text { Test } \\
\text { Second }\end{array}$ & $\begin{array}{c}\text { Class } \\
\text { Limit (x) }\end{array}$ & Z-score & BLDBKN & $\begin{array}{c}\text { Total } \\
\text { Area }\end{array}$ & $\begin{array}{c}\text { Expected } \\
\text { frequency (Ei) }\end{array}$ & $\begin{array}{c}\text { Expected } \\
\text { frequency (Oi) }\end{array}$ \\
\hline & 59.5 & -1.52612 & 0.4353 & & & 11 \\
\hline $60-64$ & & & & 0.1247 & 3.9904 & \\
\hline & 64.5 & -0.88354 & 0.3106 & & & \\
\hline $65-69$ & & & & 0.2158 & 6.9056 & 0 \\
\hline & 69,5 & -0.24097 & 0.0948 & & & 10 \\
\hline $70-74$ & & & & 0.2502 & 8.0064 & 5 \\
\hline & 74,5 & 0.40161 & 0.1554 & & & \\
\hline $79-79$ & & & & 0.1954 & 6.2528 & \\
\hline & 79.5 & 1.044119 & 0.3508 & & & \\
\hline $80-84$ & & & & 0.1027 & 3.2864 & \\
\hline & 84.5 & 1.68676 & 0.4535 & & & \\
\hline $85-89$ & & & & 0.0363 & 1.1616 & \\
\hline & 89.5 & 2.32934 & 0.4898 & & & \\
\hline Total & 521.5 & 2.81127 & 2.2902 & 0.9251 & 29.6032 & 32 \\
\hline
\end{tabular}

In which:

1. Class limit $(\mathrm{x})=$ Lower limit -0.5

$$
\begin{aligned}
& =60-0,5 \\
& =59.5
\end{aligned}
$$

2. $\mathrm{z}$ for class limits

$\mathrm{z}=\frac{x-\bar{x}}{s}$, whit $\bar{x}=71.375$ and $\mathrm{s}=0.245$

$$
\begin{aligned}
& \mathrm{z}=\frac{59.5-71.375}{0.245} \\
& \mathrm{z}=-50.51
\end{aligned}
$$

3. The area of the curve in each class is the same as the difference between

4. $\mathrm{Z}_{\mathrm{i}}$ with value $\mathrm{Z}_{(\mathrm{i}-1)}$

Total area $=\left(-\mathrm{Z}_{1}-\left(-\mathrm{z}_{2}\right)\right)$

$=(0.4353-0.3106)$

$=0.1248$

5. $\mathrm{E}_{\mathrm{i}}=$ The area of each interval class $\mathrm{x}$ many classes

$=0.1248 \times 32$

$=3.9936$

Then the value of chi-squares count is as follows:

$$
\begin{gathered}
X^{2}=\sum_{i=1}^{k} \frac{\left(0_{i-1} E_{i}\right)^{2}}{E_{i}} \\
=\frac{(11-3.9904)^{2}}{3.9904}+\frac{(0-6.9056)^{2}}{6.9056}+\frac{(10-8.0064)^{2}}{8.0064}+\frac{(5-6.2528)^{2}}{6.2528} \\
+\frac{(5-3.2864)^{2}}{3.2864}+\frac{(1-1.1616)^{2}}{1.1616}
\end{gathered}
$$


$=12.31+6.91+0.410+0.25+0.89+2.25$

$=23.02$

With a significant level $a=0.05$ and many interval classes $k=6$ then the degree of freedom $(\mathrm{dk})$ for the chi square distribution the magnitude is:

$\mathrm{dk}=\mathrm{k}-11=6-11=-2$ then $X_{\text {table }}^{2}=(1-\mathrm{a})(\mathrm{k}-11)=X^{2}(0-0.05)(6-11)=X^{2}$ $(0.95)$ (8) from the list $\mathrm{H}$ obtained values $X_{\text {table }}^{2}=7.81$. therefore $X_{\text {count }}^{2}>X_{\text {table }}^{2}$ that is 23.02 $>7.81$ so $\mathrm{H}_{0}$ is not accepted and it can be concluded that the data come from populations then are not normally distributed.

Table 9. The Combined scores of pre-test and post-test rankings

\begin{tabular}{|c|c|c|}
\hline Score & Rank & Ranking Order \\
\hline 20 & 4.5 & 1 \\
\hline 20 & 4.5 & 2 \\
\hline 20 & 4.5 & 3 \\
\hline 20 & 4.5 & 4 \\
\hline 20 & 4.5 & 5 \\
\hline 20 & 4.5 & 6 \\
\hline 20 & 4.5 & 7 \\
\hline 20 & 4.5 & 8 \\
\hline 30 & 11.5 & 9 \\
\hline 30 & 11.5 & 10 \\
\hline 30 & 11.5 & 11 \\
\hline 30 & 11.5 & 12 \\
\hline 30 & 11.5 & 13 \\
\hline 30 & 11.5 & 14 \\
\hline 35 & 17 & 15 \\
\hline 35 & 17 & 16 \\
\hline 35 & 17 & 17 \\
\hline 35 & 17 & 18 \\
\hline 35 & 17 & 19 \\
\hline 40 & 24 & 20 \\
\hline 40 & 24 & 21 \\
\hline 40 & 24 & 22 \\
\hline 40 & 24 & 23 \\
\hline 40 & 24 & 24 \\
\hline 40 & 24 & 25 \\
\hline 40 & 24 & 26 \\
\hline 40 & 24 & 27 \\
\hline 40 & 24 & 28 \\
\hline 50 & 30.5 & 29 \\
\hline 50 & 30.5 & 30 \\
\hline 50 & 30.5 & 31 \\
\hline 50 & 30.5 & 32 \\
\hline 60 & 3.8 & 33 \\
\hline 60 & 3.8 & 34 \\
\hline 60 & 3.8 & 35 \\
\hline
\end{tabular}




\begin{tabular}{|c|c|c|}
\hline 60 & 3.8 & 36 \\
\hline 60 & 3.8 & 37 \\
\hline 60 & 3.8 & 38 \\
\hline 60 & 3.8 & 39 \\
\hline 60 & 3.8 & 40 \\
\hline 60 & 3.8 & 41 \\
\hline 60 & 3.8 & 42 \\
\hline 60 & 3.8 & 43 \\
\hline 70 & 48.5 & 44 \\
\hline 70 & 48.5 & 45 \\
\hline 70 & 48.5 & 46 \\
\hline 70 & 48.5 & 47 \\
\hline 70 & 48.5 & 48 \\
\hline 70 & 48.5 & 49 \\
\hline 70 & 48.5 & 50 \\
\hline 70 & 48.5 & 51 \\
\hline 70 & 48.5 & 52 \\
\hline 70 & 48.5 & 53 \\
\hline 75 & 56 & 54 \\
\hline 75 & 56 & 55 \\
\hline 75 & 56 & 56 \\
\hline 75 & 56 & 57 \\
\hline 75 & 56 & 58 \\
\hline 80 & 61 & 59 \\
\hline 80 & 61 & 60 \\
\hline 80 & 61 & 61 \\
\hline 80 & 61 & 62 \\
\hline 80 & 61 & 63 \\
\hline 85 & 64 & 64 \\
\hline
\end{tabular}

Rank each data in the group cell. There is the same data in table 10 which is 60 appears five times then 20(8), 30(6), 35(5), 40(9) and 50(4), 60(11),70(10), 75(5), and 80(5). The, rank calculation for the same data that is:

$$
\begin{array}{ll}
20(8)-\mathrm{R}=\frac{36}{8}=4.5 & 60(11)-\mathrm{R}=\frac{418}{11}=38 \\
30(6)-\mathrm{R}=\frac{58}{6}=9.67 & 70(10)-\mathrm{R}=\frac{485}{10}=48.5 \\
35(5)-\mathrm{R}=\frac{85}{5}=17 & 75(5)-\mathrm{R}=\frac{333}{5}=66.6 \\
40(9)-\mathrm{R}=\frac{216}{9}=24 & 80(5)-\mathrm{R}=\frac{305}{5}=61 \\
50(4)-\mathrm{R}=\frac{122}{4}=30.5 &
\end{array}
$$

Regroup the data that has been ranked into the initial group of observations 
Table 10. The score of the ability to count rank 1 and rank 2 pre-test and post-test

\begin{tabular}{|c|c|c|c|c|c|}
\hline Students & Score & Rank & Students & Score & Rank \\
\hline 1 & 20 & 4.5 & 1 & 60 & 3.8 \\
\hline 2 & 20 & 4.5 & 2 & 60 & 3.8 \\
\hline 3 & 20 & 4.5 & 3 & 60 & 3.8 \\
\hline 4 & 20 & 4.5 & 4 & 60 & 3.8 \\
\hline 5 & 20 & 4.5 & 5 & 60 & 3.8 \\
\hline 6 & 20 & 4.5 & 6 & 60 & 3.8 \\
\hline 7 & 20 & 4.5 & 7 & 60 & 3.8 \\
\hline 8 & 20 & 4.5 & 8 & 60 & 3.8 \\
\hline 9 & 30 & 11.5 & 9 & 60 & 3.8 \\
\hline 10 & 30 & 11.5 & 10 & 60 & 3.8 \\
\hline 11 & 30 & 11.5 & 11 & 60 & 3.8 \\
\hline 12 & 30 & 11.5 & 12 & 70 & 48.5 \\
\hline 13 & 30 & 11.5 & 13 & 70 & 48.5 \\
\hline 14 & 30 & 11.5 & 14 & 70 & 48.5 \\
\hline 15 & 35 & 17 & 15 & 70 & 48.5 \\
\hline 16 & 35 & 17 & 16 & 70 & 48.5 \\
\hline 17 & 35 & 17 & 17 & 70 & 48.5 \\
\hline 18 & 35 & 17 & 18 & 70 & 48.5 \\
\hline 19 & 35 & 17 & 19 & 70 & 48.5 \\
\hline 20 & 40 & 24 & 20 & 70 & 48.5 \\
\hline 21 & 40 & 24 & 21 & 70 & 48.5 \\
\hline 22 & 40 & 24 & 22 & 75 & 56 \\
\hline 23 & 40 & 24 & 23 & 75 & 56 \\
\hline 24 & 40 & 24 & 24 & 75 & 56 \\
\hline 25 & 40 & 24 & 25 & 75 & 56 \\
\hline 26 & 40 & 24 & 26 & 75 & 56 \\
\hline 27 & 40 & 24 & 27 & 80 & 61 \\
\hline 28 & 40 & 24 & 28 & 80 & 61 \\
\hline 29 & 50 & 30.5 & 29 & 80 & 61 \\
\hline 30 & 50 & 30.3 & 30 & 80 & 61 \\
\hline 31 & 50 & 30.5 & 31 & 80 & 61 \\
\hline 32 & 50 & 30.5 & 32 & 85 & 64 \\
\hline Total & $\mathrm{R}_{1}$ & 528 & Total & & 1552 \\
\hline
\end{tabular}

Based on table 9 obtained $\mathrm{R}_{1}=528$ and $\mathrm{R}_{2}=1552$

Determine average $R_{1}$ the average $R_{2}$, standard error ranking and $Z_{\text {count }}$ with the following formula:

$$
\begin{aligned}
& \mu \mathrm{R}_{1}=\frac{n 1(n 1+n 2+1)}{5}=\frac{34(34+30+1)}{5}=\frac{34(65)}{5}=\frac{2.210}{5}=0.442 \\
& \mathrm{\gamma}_{\mathrm{R}}=\frac{\sqrt{\mathrm{n} 1 \times \mathrm{n} 2 \times(\mathrm{n} 1+\mathrm{n} 2+1)}}{11}=\frac{\sqrt{34 \times 30 \times(34+30+1)}}{11}
\end{aligned}
$$




$$
\begin{aligned}
& \mathrm{C}_{\mathrm{R}}=\frac{\sqrt{1.020 X 65}}{11}=\frac{\sqrt{66.3}}{11}=\sqrt{6.027}=2.45 \\
& \mathrm{Z}_{\text {count }}=\frac{R 1-\mu \mathrm{R} 1}{\mathrm{sR}}=\frac{528-0.442}{2.45}=\frac{527.558}{2.45}=215.33
\end{aligned}
$$

Determine the point of criticism $\mathrm{z}_{\text {table }}=1.67$

Make conclusions namely a two-party test: $=\mathrm{z}_{\text {count }} 215.33$ and $\mathrm{z}_{\text {table }} 1.67$ then $\mathrm{z}_{\text {count }}>$

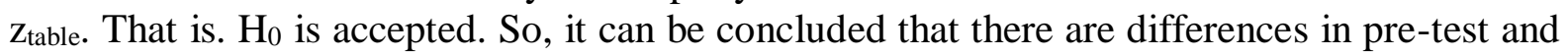
post-test.

\section{Analysis of Questionnaires}

The questionnaires were distributed to the respondents because the researcher wanted to know the students' response toward the application of STT in increasing students' speaking skill. In analyzing the questionnaires, the researcher used the percentage system, and the formula is as suggested by Sudjana, (2005: 67)

$$
p=\frac{f}{n} \times 100 \%
$$

In which: $\mathrm{p}=$ Percentage

$\mathrm{f}=$ Frequency of respondents

$\mathrm{n}=$ Number of respondents

$100=$ Constant value

Furthermore the data can be seen in the following tables.

Table 11. The students' difficulties in learning speaking

\begin{tabular}{|l|l|c|c|}
\hline \multicolumn{1}{|c|}{ Question } & Option & F & \% \\
\hline \multirow{3}{*}{$\begin{array}{l}\text { 1. Is learning speaking difficult for } \\
\text { you? }\end{array}$} & A. Difficult & 14 & $43.75 \%$ \\
\cline { 2 - 4 } & B. Not difficult & 7 & $21.875 \%$ \\
\cline { 2 - 4 } & C. Quite difficult & 11 & $34.375 \%$ \\
\cline { 2 - 4 } & D. Very difficult & 0 & $0 \%$ \\
\hline & Total & $\mathbf{3 2}$ & $\mathbf{1 0 0 \%}$ \\
\hline
\end{tabular}

The result of the table above showed that the most of the students $(43.75 \%)$ said that it was difficult in learning speaking for them, 11 students $(34.375 \%)$ chose point $\mathrm{C}$ that learning speaking is quite difficult for them, 7 students $(21.875 \%)$ said that learning speaking is not difficult and none of them stated that learning speaking is very difficult. So, it can be concluded that learning speaking is difficult.

Table 12. The students' obstacles in speaking

\begin{tabular}{|c|l|c|c|}
\hline Question & Option & F & \% \\
\hline \multirow{2}{*}{$\begin{array}{c}\text { 2. What obstacles } \\
\text { did you face in } \begin{array}{c}\text { Tid } \\
\text { speaking? }\end{array}\end{array}$} & A. Lack of vocabulary mastery & 14 & $43.75 \%$ \\
\cline { 2 - 4 } & B. Difficult in pronounciation & 14 & $43.75 \%$ \\
\cline { 2 - 4 } & C. Lack of speaking strategy & 0 & $0 \%$ \\
\cline { 2 - 4 } & D. Lack of interest and concentration & 4 & $12.5 \%$ \\
\hline & Total & $\mathbf{3 2}$ & $\mathbf{1 0 0 \%}$ \\
\hline
\end{tabular}


It can be seen from the table above, 14 students (43.75\%) chose point A and B in answering the question that the obstacles faced by them in speaking because of lack of vocabulary mastery and they difficult in producing the pronounciation. In addition, 4 students $(12.5 \%)$ chose point $\mathrm{D}$, that they lack of interest and contention in speaking. However, none of students chose point $\mathrm{C}$ lack of speaking strategy.

Table 13. The students' disability in speaking

\begin{tabular}{|l|l|c|c|}
\hline \multicolumn{1}{|c|}{ Question } & Option & F & \% \\
\hline \multirow{2}{*}{$\begin{array}{l}\text { 3. In your opinion, } \\
\text { what is your } \\
\text { problems in } \\
\text { speaking English? }\end{array}$} & A. Many difficult vocabulary & 8 & $25 \%$ \\
\cline { 2 - 4 } & B. Different writing and pronounciation & 18 & $56.25 \%$ \\
\cline { 2 - 4 } & C. Lack of vocabulary & 4 & $12.5 \%$ \\
\cline { 2 - 4 } & D. Do not know & 2 & $6.25 \%$ \\
\hline \multicolumn{1}{|c|}{ Total } & $\mathbf{3 2}$ & $\mathbf{1 0 0 \%}$ \\
\hline
\end{tabular}

Table 14. The students' does not interested in speaking

\begin{tabular}{|c|c|c|c|}
\hline Question & Option & $\mathbf{F}$ & $\%$ \\
\hline \multirow{4}{*}{$\begin{array}{l}\text { 4. In your opinion, } \\
\text { what causes a } \\
\text { person does not } \\
\text { interested in } \\
\text { speaking? }\end{array}$} & A. Frequently use of mother tongue & 1 & $3.125 \%$ \\
\hline & $\begin{array}{l}\text { B. Constrained with the lack of } \\
\text { vocabulary }\end{array}$ & 16 & $50 \%$ \\
\hline & $\begin{array}{l}\text { C. Differentiation of writing and } \\
\text { speaking }\end{array}$ & 12 & $37.5 \%$ \\
\hline & D. Do not know & 3 & $9.375 \%$ \\
\hline & Total & 32 & $100 \%$ \\
\hline
\end{tabular}

The table shows that, 16 students $(50 \%)$ chose point B that the causes of students does not interested in speaking because they constrained with the lack of vocabulary. 12 students (37.5\%) chose point $\mathrm{C}$ that differently of writing and speaking when they produce the speaking especially English and 3 students $(9.375 \%)$ chose point D that they do not know why the students does not interested in speaking English and only 1 student $(3.125 \%)$ chose point A which frequently use of mother tongue in engage the conversation with their friends.

Table 15. The students' interested in learning speaking by using story telling Technique.

\begin{tabular}{|l|l|c|c|}
\hline \multicolumn{1}{|c|}{ Question } & Option & F & \% \\
\hline \multirow{2}{*}{$\begin{array}{l}\text { 5. Do you interested in } \\
\text { learning speaking by } \\
\begin{array}{l}\text { using story telling } \\
\text { technique? }\end{array}\end{array}$} & A. Interested & 12 & $37.5 \%$ \\
\cline { 2 - 4 } & B. Not interested & 7 & $21.875 \%$ \\
\cline { 2 - 4 } & C. Very interested & 4 & $12.5 \%$ \\
\cline { 2 - 4 } & D. Quite interested & 9 & $28.125 \%$ \\
\hline & Total & $\mathbf{3 2}$ & $\mathbf{1 0 0 \%}$ \\
\hline
\end{tabular}

Table 16. The students'improvement in learning speaking by using story telling Technique

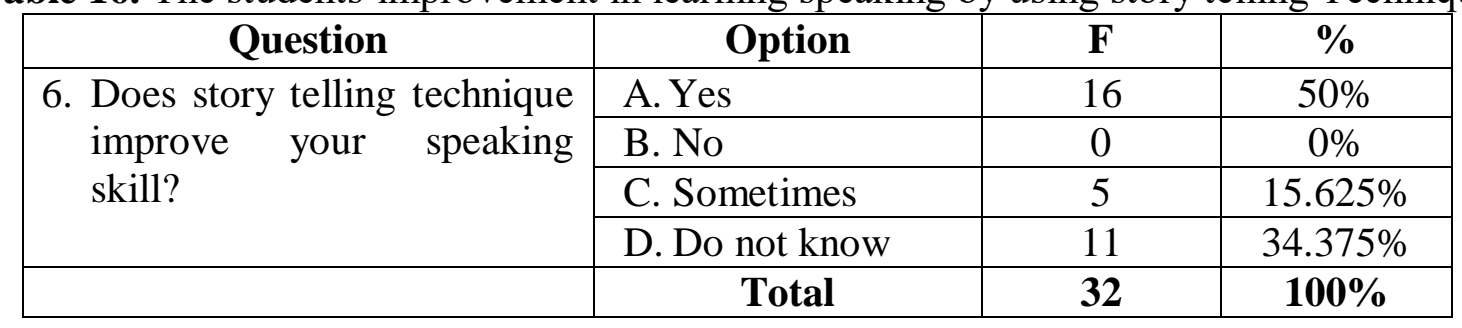


The table above shows that, 16 students (50\%) said that the technique improve their speaking skill. 11 students $(34.375 \%)$ chose point $\mathrm{D}$ that they do not know wheater of the technique improve their speaking skill or not. 5 students $(15.625 \%)$ said that sometimes the technique and none of them stated that the story telling technique is not improve their speaking skill. So, it can be concluded improve their speaking. That story telling technique could improve students' speaking skill.

Table 17. The students'learning speaking by using STT

\begin{tabular}{|c|c|c|c|}
\hline Question & Option & $\mathbf{F}$ & $\%$ \\
\hline \multirow{5}{*}{$\begin{array}{l}\text { 7. Have you ever learnt speaking } \\
\text { by using story telling } \\
\text { technique? }\end{array}$} & A. Ever & 12 & $37.5 \%$ \\
\hline & B. Never & 11 & $34.375 \%$ \\
\hline & C. Often & 2 & $6.25 \%$ \\
\hline & D. Sometimes & 7 & $21.875 \%$ \\
\hline & Total & 32 & $100 \%$ \\
\hline
\end{tabular}

From the table above, it can be seen that 12 students (37.5\%) chose point A that they ever learnt speaking by using STT. 11 students $(34.375 \%)$ chose point B said that they never learnt speaking by using STT and 7 students $(21.875 \%)$ chose point D that they sometimes learnt speaking by using STT and only 2 students $(6.25 \%)$ chose point c, they often learnt speaking by using story telling technique. So, it can be concluded that the students ever learnt speaking by using STT at the school.

Table 18. Could the STT improve the students' vocabulary

\begin{tabular}{|l|l|c|c|}
\hline \multicolumn{1}{|c|}{ Question } & \multicolumn{1}{|c|}{ Option } & F & \% \\
\hline $\begin{array}{l}\text { 8. Does STT could improve } \\
\text { students' vocabulary? }\end{array}$ & A. Yes & 22 & $68.75 \%$ \\
\cline { 2 - 4 } & B. No & 1 & $3.125 \%$ \\
\cline { 2 - 4 } & C. Sometimes & 5 & $15.625 \%$ \\
\cline { 2 - 4 } & D. Do not know & 4 & $12.5 \%$ \\
\hline & \multicolumn{1}{|c|}{ Total } & $\mathbf{3 2}$ & $\mathbf{1 0 0 \%}$ \\
\hline
\end{tabular}

From the table above, it can be seen that 22 students $(68.754 \%)$ chose point $\mathrm{A}$ that the STT could improve students' vocabulary, 5 students $(15.625 \%)$ chose point C that the technique sometimes could increase their vocabulary, 4 students $(12.5 \%)$ chose point D that they do tot know wheather the technique could improve their vocabulary and only 1 students $(3.125 \%)$ stales that the technique could not enhance his vocabulary. So, it can be concluded that the technique could improve, increase and enhance students' vocabulary.

Table 19. The students'motivate in learning speaking

\begin{tabular}{|c|l|c|c|}
\hline Question & \multicolumn{1}{|c|}{ Option } & F & \% \\
\hline \multirow{2}{*}{$\begin{array}{c}\text { 9. Does the technique motivate } \\
\text { students' in learning speaking? }\end{array}$} & A. Yes & 15 & $46.875 \%$ \\
\cline { 2 - 4 } & B. No & 5 & $15.625 \%$ \\
\cline { 2 - 4 } & C. Sometimes & 4 & $12.5 \%$ \\
\cline { 2 - 4 } & D. Do not know & 8 & $25 \%$ \\
\hline & \multicolumn{1}{|c|}{ Total } & $\mathbf{3 2}$ & $\mathbf{1 0 0 \%}$ \\
\hline
\end{tabular}

From the table above, it can be seen that 15 students $(46.875 \%)$ chose point A that they motivate in learning speaking, 8 students $(25 \%)$ said that do not know wheather the technique motivate them in learning, 5 students $(15.625 \%)$ chose point B that they have no 
motivation in learning speaking by using the technique and only 4 students $(12.5 \%)$ chose point $\mathrm{C}$, that they sometimes motivated in learning speaking by using the technique motivate students' in learning speaking. So, it can be concluded that the

Table 20. The students'easier to tell stories by using English

\begin{tabular}{|c|l|c|c|}
\hline Question & \multicolumn{1}{|c|}{ Option } & F & \% \\
\hline \multirow{3}{*}{$\begin{array}{l}\text { 10. Does STT is easier in telling } \\
\text { story in English? }\end{array}$} & A. Yes & 20 & $62.5 \%$ \\
\cline { 2 - 4 } & B. No & 3 & $9.375 \%$ \\
\cline { 2 - 4 } & C. Sometimes & 2 & $6.25 \%$ \\
\cline { 2 - 4 } & D. Do not know & 7 & $21.875 \%$ \\
\hline & \multicolumn{1}{|c|}{ Total } & $\mathbf{3 2}$ & $\mathbf{1 0 0 \%}$ \\
\hline
\end{tabular}

From the table above, it can be seen that 20 students $(62.5 \%)$ chose point A that they are easier in learning speaking by using STT, 7 students $(21.85 \%)$ chose point D that they do not know wheather STT is easier for them in learning speaking, only 2 students $(6.25 \%)$ chose point $\mathrm{C}$ that sometime the technique is easier in learning speaking and 3 students $(9.375 \%)$ chose point B that the technique does not make them easy in learning speaking.

\section{Conclusion}

Based on the previous explanation and analysis, the researcher would like to read some conclusion from the result of the students' achievement at MTsN 2 Aceh Besar, Tungkob. Many students like to study speaking ability by using story telling technique. In other word, the students are interested in studying speaking ability by using story tellng technique. There is significant of experimental class. From statistical analysis, it is found that the experimental class speking ability achievement after the implementation by using story telling technique is better than the experimental class speaking ability before the implementation by using story telling technique.

\section{References}

Akhyak \& Indramawan, A. (2013). Improving the Students' English Speaking Competence through Story Telling (Study in Pangeran Diponegoro islamic college (STAI) of Nganjuk, East Java, Indonesia). International Journal of Language and Literature. Accessed on 5th May 2019.

Ary, D. Jacobs, L. C. dan Sorensen, C. (2010). Introducing to research in Education .UAS. Wadsworth.

Asfandiyar, Y. (2007). Cara Pintar Mendongeng. Cetakan I. Bandung:Mizan Media Utama.

Aye, K. K. \& Phyu, K. L. (2015). Developing students' Speaking Skill through Short Stories. Yangon University of Education Research Journal.

Fikriah. (2016). Using the Story Telling Technique to Improve English Speaking Skills of Primary School Students. English Education Journal (EEJ). Accessed on 7th June 2019.

Gert and Hans. (2012). Improving Students' Speaking through Communicative Language Teaching Method at Mts Ja-alhaq, Sentot Ali Basa Islamic boarding School of Bengkulu, Indonesia. International Journal of Humanities and Social Science. Accessed on 6th June 2019.

Hasibuan, S.C., et al. (2019). Development of Child Worksheets Based on the Story as Subtheme "My Body" to Improve Students' Speaking Abilities at Al-Ikhlas Early Childhood Education and Development (ECED) Medan Amplas. Budapest 
International Research and Critics in Linguistics and Education (BirLE) Journal, P. 539-546.

Hornby. (1995). Oxford Advanced Learner's Dictionary of Current Language. Oxford: Oxford University Press.

Oller JR and John W. (1979). Language Test at School. London: Longman.

Oxford Advanced Learner's Dictionary (2000). Oxford: Oxford University Press.

Samantaray, P. (2014). Use of Story Telling Method to Develop Spoken English Skill. International Journal of Language \& Linguistics. Accessed on 13th Sept 2019.

Sari, A.S.P., and Sembiring, R.K.B. (2019). Improving Students' English Speaking Skill Through the Implementation of Talking Stick Method to the Fifth Grade Students of State Primary School 028226 Binjai. Budapest International Research and Critics in Linguistics and Education (BirLE) Journal, P. 507-513.

Sepahvand,H. (2014). The Effect of Oral Reproduction of Short Stories on Speaking Skill in Iranian high school students (case study: khorram abad, Iran). International Journal of Science and Research (IJSR). Accessed on 10th Sept 2019.

Sutrisno. (1965). Metode Stastistik. Yogyakarta. Andi Offest.

Tahir, S. Z. A. (2015). Improving Students' Speaking Skill through Yahoo Messenger at University of Iqra Buru. International Journal of Language and Linguistics. Accessed on 14th Sept 2019.

Tarigan,H.G.(2015) Berbicara Keterampilan Berbahasa. Bandung: Angkasa.

Zaro, J.J \& Salaberri, S. (1995) Story telling. Macmillan. 